\title{
MODELLING THE DISTRIBUTION OF WETLAND BIRDS ON THE RED SEA COAST IN THE KINGDOM OF SAUDI ARABIA
}

\author{
ALMALKI, M. ${ }^{1} *$ - ALRASHIDI, M. ${ }^{2}-$ O'CONNELL, M.J. ${ }^{3}$-SHOBRAK, M. ${ }^{4}$-SZÉKELY, T. ${ }^{1}$ \\ ${ }^{I}$ Department of Biology and Biochemistry, University of Bath, Claverton Down, Bath \\ $B A 27 A Y, U K$. \\ (phone: +44-(0)-1225-384-238) \\ ${ }^{2}$ Department of Biology, College of Science, University of Hail, \\ P.O. Box 2440, Hail, Saudi Arabia. \\ (phone: +96-6-5047-111-300) \\ ${ }^{3}$ Ecological Research \& Training ltd, Stroud, Gloucestershire \\ GL5 1RT, UK. \\ (phone:+44-(0)-7760-102-173) \\ ${ }^{4}$ Department of Biology, College of Science, Taif University \\ P.O. Box 888, Taif, Saudi Arabia. \\ (phone: +96-6-505-721-001) \\ *Corresponding author \\ e-mail:msam21@bath.ac.uk \\ (Received $3^{\text {rd }}$ Oct 2013; accepted $14^{\text {th }}$ Aug 2014)
}

\begin{abstract}
Species distribution modelling is useful for addressing knowledge gaps for poorly studied geographical areas by identifying potentially suitable habitats for species across landscapes. This study was undertaken to identify areas containing wetland habitats to support actions aimed at the conservation of wetland bird species on the Red Sea coast of the Kingdom of Saudi Arabia (KSA). We used a maximum entropy approach to build habitat suitability models for 22 wetland bird species (gulls, shorebirds, and terns). Ten variables relating to topography, habitat, latitude, coast complexity, man-made structures, and human settlements were used to produce individual habitat suitability models for each of the bird species. The areas under the curve (AUC) for the final model were 0.9013 and 0.879 for the training and testing data, respectively, and the jackknife analyses suggested that the models generally performed well. Using the modelled distributions of the 22 species along the Red Sea coast, the analysis suggested 17 core areas where the habitat and landscape configuration were suitable for supporting high species richness. Of these 17 sites, one is already protected, and there is a need to protect the remaining sites. The use of these models to inform conservation strategies in the Red Sea region of the KSA is discussed.
\end{abstract}

Keywords: wetland birds, Red Sea coast, species distribution model, MaxEnt.

\section{Introduction}

The Red Sea region has diverse coastal and marine habitats. These include mangroves, mudflats, marshes, sand dunes, sand plains, rocky shores, coastal reefs, and marine islands (PERSGA/GEF, 2003). The region is particularly important for corals, marine invertebrates, and turtles (AbuZinada et al., 2002).

However, the size of the region and limited opportunities for survey and census fieldwork, mean that the fauna of the Red Sea coast remains relatively poorly studied.

Previous surveys have suggested that the region is important for a variety of bird taxa, including Palaearctic migrants and winter residents (PERSGA/GEF, 2004). On the Red 
Sea coast and the Gulf of Aden, 17 seabird species have been recorded as breeding, including endemic species such as White-eyed Gull (Larus leucophthalmus), a subspecies of the Red-billed Tropicbird (Phaeton aethereus indicus) and the Brown Noddy (Anous stolidus plumbeigularus). Furthermore, some species endemic to the northwest Indian Ocean and important sub-populations breed in the region such as Jouanin's Petrel (Bulweria fallax), Sooty Gull (Larus hemprichii), Swift Tern (Sterna bergii velox), and White-cheeked Tern (Sterna repressa) (PERSGA/GEF, 2004). This region includes Socotra Cormorant (Phalacrocorax nigrogularis) that is classified as 'threatened', with three further species classified as 'near threatened' on the IUCN Red List (IUCN, 2012): Jouanin's Petrel, Persian Shearwater (Puffinus persicus), and Whiteeyed Gull that are classified as being 'near threatened' on the IUCN Red List (PERSGA/GEF, 2004). Furthermore, AlRashidi et al. (2011) found that some sites of the Red Sea coast are highly suitable for breeding and wintering Kentish Plover (Charadrius alexandrinus).

Despite its relative isolation, the Red Sea coast is subject to growing human pressures. In particular there has been an issue with coastal development and pollution (PERSGA/GEF, 2004). Moreover, the taking of seabird eggs is a potential problem in the region and needs regulation and/or sustainable take agreements (Newton, 2006).

Within the Red Sea area, research and monitoring was one of seven priority 'enabling' actions identified in the 2004 PERSGA report (PERSGA/GEF, 2004). Understanding the complex ecological relationships between species distribution, environmental structure and human pressure is of high utility for the development of: (i) Integrated Coastal Zone Management (ICZM) frameworks, (ii) the identification of protected sites and networks, and (iii) effective evaluation of conservation activities. The present project is one of only a small number of research initiatives that have so far been undertaken in the region.

Despite the need for greater understanding species-habitat relationships, modelling wetland birds in the Red Sea region can be problematic because of the lack of range and gradients of the landscape's physical features AlRashidi et al. (2011).

Recent field monitoring efforts at key seabird sites and greater availability of high resolution data from the region now make it possible to develop species distribution models (SDMs). Recent testing of SDMs using biological data (including birds) has shown that robust biologically relevant models can be developed from the integration of 'presence only' observations of species occurrence with measurements of environmental characteristics. These models predict the actual or potential distribution of a species (Elith and Leathwick, 2009), and provide an understanding of the underlying species-habitat relationships (Guisan and Zimmermann, 2000; Franklin, 2009). SDMs have also been used for estimating the effects of climate change (Buckland et al., 1996; Austin et al., 1996; Thomas et al., 2004), estimating population size (Long et al., 2008), understanding the correlation between distribution and abundance (Milsom et al., 2000; Ledee et al., 2008), conservation planning and forecasting (Rushton et al., 2004; Phillips and Dudík, 2008), and species distribution monitoring (Rodriguez et al., 2007).

Species distribution models require detailed information about the environment of the study area, and species occurrence data. This can be either presence-only data or presence- absence data (Graham et al., 2008). In practice, 'true' absence data are rarely available, because they require a considerable amount of time and effort to collect and it can be difficult to ensure that there are no false-negatives in the data. The vast 
majority of datasets for species distribution modelling are therefore presence-only datasets (Phillips et al., 2006), and this is the case for the present study.

To address the current lack of understanding about factors driving the abundance and distribution of shorebirds along the Red Sea coast of the Kingdom of Saudi Arabia (KSA), we have utilised available data from an extensive coastal bird survey (AlRashidi et al., 2011), to attempt the first species distribution modelling in the region. The core aim of this research was therefore to give guidance for the development of conservation strategies for the Red Sea coastal area of the KSA by providing a better understanding of the distribution of 22 wetland bird species along the Red Sea coast. Therefore, this will help guide future surveys and monitoring of wetland bird species in this region. We also targeted to quantify the relative importance of key sites by determining areas of high species richness.

\section{Methods}

\section{Environmental variables for the model}

The Red Sea coastline of the KSA extends 1,840 kilometres from the border with Jordan in the northern Gulf of Aqaba region $\left(29^{\circ} 30^{\prime} \mathrm{N}\right)$ to the border with Yemen in the southern Red Sea region (16 ${ }^{\circ} 22^{\prime}$ N) (PERSGA/GEF, 2003). This coastline has an arid climate with temperatures reaching up to $50{ }^{\circ} \mathrm{C}$ in summer. The average rainfall is less than $70 \mathrm{~mm}$ per year (PERSGA/GEF, 2003).

We utilised the wetland bird species data collected by AlRashidi et al. (2011) between 2 July and 10 August 2008 (Fig. 1). The data were gathered from 98 randomly selected sites located within $1 \mathrm{~km}$ of the sea along the west coast of Saudi Arabia including the Farasan Islands. 35 bird species have been recorded along the Red Sea coast, and here we focus on 22 of these species, for which more than 14 records were available (Table 1).

Ten environmental variables were selected for the species distribution modelling: vegetation cover, soil moisture, distance to main cities (big cities), distance to cities (small cities), distance to roads, brightness, latitude, coast complexity, elevation, and slope. Information about vegetation cover, soil moisture, brightness, and elevation was derived from 21 Landsat 7 satellite images and rendered into GIS format (below) by online tools associated with the Global Land Cover Facility (AlRashidi et al., 2011).

The tasseled cap transformation was introduced by Kauth and Thomas (1976). It is an appropriate tool for improving spectral data and deriving important environmental information (Crist and Cicone, 1984). A tasselled cap transformation with coefficients for the Landsat ETM+ sensor was used (Huang et al., 1998) to produce three rasters: tasselled cap greenness shows the existence and density of green vegetation; tasselled cap moistness, which describes the amount of soil moisture; and tasseled cap brightness, shows variations in soil structures. Finally, all transformed images were rescaled such that pixels took digital number values from 0 to 255 (see AlRashidi et al., 2011; Long et al., 2008).

Elevation data were derived from the Shuttle Radar Topography Mission (SRTM). Tiles of SRTM data corresponding to the 21 WRS-2 scenes of Landsat data used were downloaded from the Global Landcover Facility (http://www.landcover.org). These were then mosaiced and clipped in the same way as the satellite images were. The resolution of this dataset was $90 \mathrm{~m}$, but in order to overlay all layers of environmental 
data exactly, we resampled the SRTM to $30 \mathrm{~m}$ pixel size to produce the final elevation map (see AlRashidi et al., 2011; Long et al., 2008).

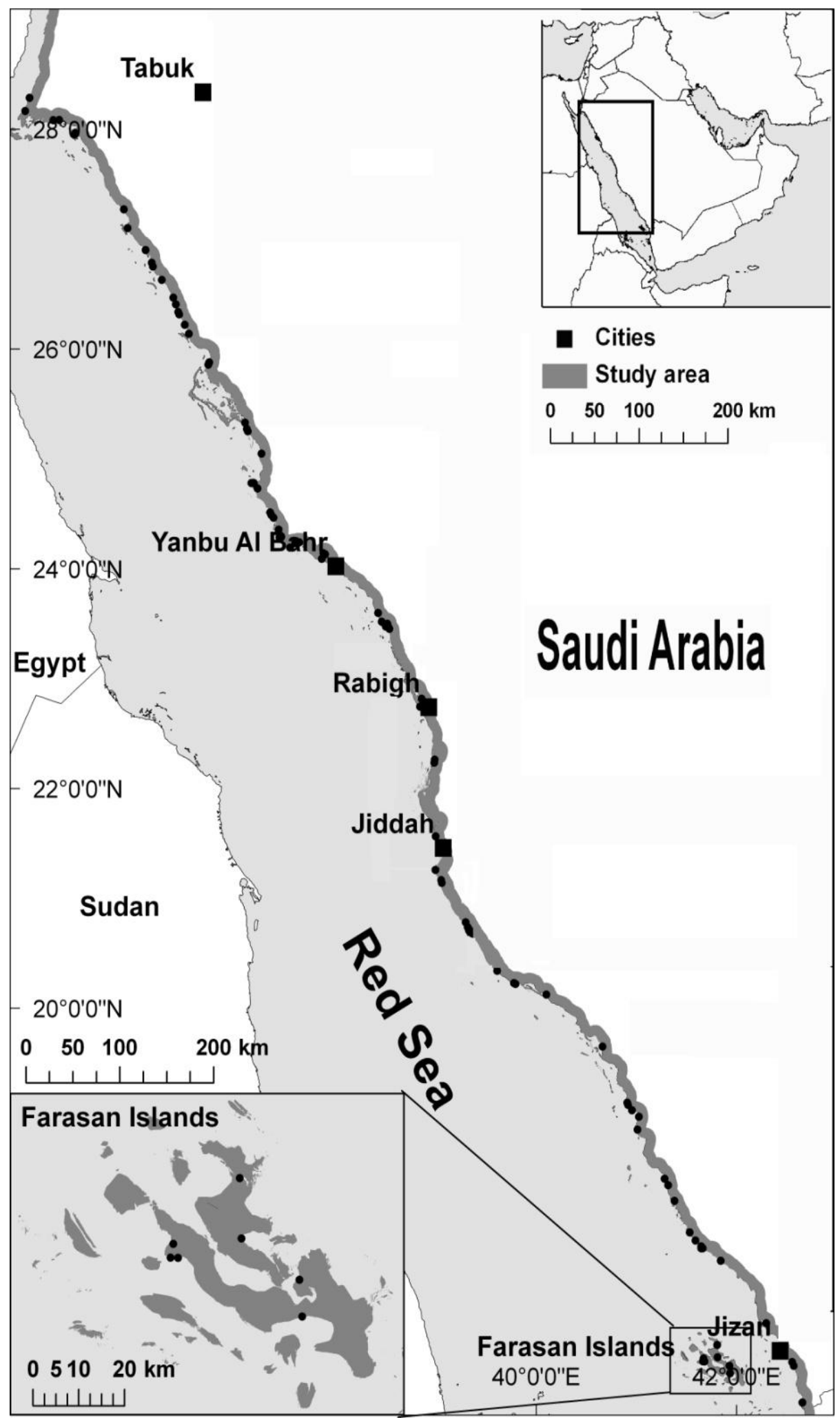

Figure 1. Map showing the study area on the west coast of Saudi Arabia (shaded dark grey); black dots represent starting points of 98 randomly selected sites (AlRashidi et al., 2011) 
Table 1. The 22 wetland bird species included in distribution modelling

\begin{tabular}{|c|c|c|c|c|}
\hline No & Species & Scientific name & $\begin{array}{l}\text { Threat status } \\
\text { (IUCN 2012) }\end{array}$ & $\begin{array}{c}\text { Population } \\
\text { trend } \\
\text { (IUCN 2012) }\end{array}$ \\
\hline 1 & Eurasian Spoonbill & Platalea leucorodia & LC & unknown \\
\hline 2 & Intermediate Egret & Mesophoyx intermedia & LC & decreasing \\
\hline 3 & Western Reef Heron & Egretta gularis & LC & stable \\
\hline 4 & Pink-backed Pelican & Pelecanus rufescens & LC & stable \\
\hline 5 & Eurasian Oystercatcher & Haematopus ostralegus & LC & decreasing \\
\hline 6 & Crab Plover & Dromas ardeola & LC & stable \\
\hline 7 & Kentish Plover & Charadrius alexandrinus & LC & decreasing \\
\hline 8 & Lesser Sand Plover & Charadrius mongolus & LC & unknown \\
\hline 9 & Greater Sand Plover & Charadrius leschenaultii & LC & Unknown \\
\hline 10 & Whimbrel & Numenius phaeopus & LC & decreasing \\
\hline 11 & Eurasian Curlew & Numenius arquata & NT & decreasing \\
\hline 12 & Redshank & Tringa totanus & LC & unknown \\
\hline 13 & Marsh Sandpiper & Tringa stagnatilis & LC & decreasing \\
\hline 14 & Terek Sandpiper & Xenus cinereus & LC & stable \\
\hline 15 & Ruddy Turnstone & Arenaria interpres & LC & decreasing \\
\hline 16 & White-eyed Gull & Larus leucophthalmus & NT & stable \\
\hline 17 & Sooty Gull & Larus hemprichii & LC & decreasing \\
\hline 18 & Caspian Tern & Sterna caspia & LC & increasing \\
\hline 19 & Swift Tern & Sterna bergii & LC & stable \\
\hline 20 & Lesser Crested Tern & Sterna bengalensis & LC & stable \\
\hline 21 & Saunders's Tern & Sterna saundersi & LC & decreasing \\
\hline 22 & White-cheeked Tern & Sterna repressa & LC & decreasing \\
\hline
\end{tabular}

As a proxy measure of human impact, we made a data layer showing the distance to the nearest main cities, cities and roads. A point shapefile containing all buildings on 
the west coast of Saudi Arabia was projected to UTM 37N and clipped to the study area. The source of these data was http://www.gospatial.com. Three distance-to-feature rasters were created to measure the euclidean distance between all cells within the study area to the nearest main cities, cities and roads. We then converted the data to raster format in which each cell took as its value the distance $(\mathrm{km})$ to the nearest main cities, cities and roads (see AlRashidi et al., 2011).

To investigate the effect of latitude, we added latitude coordinate data in ArcGIS as a layer with decimal degrees format. We then converted the data to raster format. After that, raster was clipped to the study area to generate the latitude layer that matches all layers of environmental data exactly. We then converted raster to ASCII.

To investigate the effect of coastal complexity (the physical shape attributes of each coastal pixel), a fishnet layer was created to split the coastline into $1 \mathrm{~km}^{2}$. Next, we calculated the geometric intersection of the feature classes and feature layers. We then converted the data to raster format in which the value of each cell was given an indication of how curvy the coastline is. Finally, this raster was clipped to the study area to generate the coast complexity map that matches all layers of environmental data exactly. We then converted raster to ASCII.

\section{Species data}

The species occurrence data were entered into ArcGIS version 10, re-projected to UTM in the same coordinate system, and then rasterised. All environmental variables (described above) were converted to raster layers within ArcGIS, and modified to fit the same geographical boundary and cell size. Finally, we converted the environmental layers from raster format to ASCII and exported them to the modelling program.

\section{Species distribution modelling}

All analyses were implemented using MaxEnt software version 3.3.3e (Phillips et al., 2006). MaxEnt uses presence-only data to predict the likelihood distributions of maximum entropy as the basis for forecasts of potential distributions of species (Young et al., 2009).

The models were estimates of the maximum and the most uniform spread of a species across a study area, based on environmental constraints. An internal regularisation technique is used to control overfitting data (Phillips et al., 2006). The output of MaxEnt was a raster map of the same resolution as the input data; each cell represented the relative suitability of an area for a species to reside there. The value of each cell is re-scaled from 0 to 1 , with zero being the lowest and 1 being the highest probability of suitability (Phillips et al., 2006).

MaxEnt's jackknife options were used to investigate the relative importance of the environmental variables. The gain is a measure of the probability of the samples; which specifically maximizes the likelihood of the presence samples with reference to the background data. Thus, the higher gain value denoting a better fit of model. (Phillips et al., 2006). For each candidate model set/species, ten replicate models were run and model averages were taken across the set in order to display the distribution of wetland birds as a species group. Sufficient data were available to allow replicate models to be run with a split 50\% training data and 50\% test data.This permits an evaluation of the model's performance. 
To produce an indication of the distribution of wetland birds as an assemblage of wetland bird species and to estimate the proportion of suitable habitats along the Red Sea coast, Maxent was run with a single model based on all of the 22 bird species to give "All birds" model, where presence equal the presence of any species. After that, the Maxent map of "All birds", was imported into Arc GIS and cells with a habitat suitability probability of $<0.7$ were given the value 0 (not suitable) and those with a probability $>1$ given a value of 1 (likely to be suitable habitat). The proportions of suitable and unsuitable habitat cells were then calculated.

\section{Evaluation of the models}

The predictive performance of the models was tested using receiver-operating characteristics (ROC). The area under the curve (AUC) was then used as a measure of model performance; the value of AUC was scaled from 0 to 1 , where 1 is optimal performance, 0.5 is no better than random, and less than 0.5 is worse than random (Elith et al., 2006; Pearce and Ferrier, 2000).

22 species models were used to build the species richness map. Maximum training sensitivity plus specificity was used to determine the threshold value necessary to predict unsuitable and suitable habitats for each species model. According to JiménezValverde and Lobo (2007), the resulting threshold generally achieves high prediction accuracy. In order to apply the maximum training sensitivity plus the specificity threshold to each species, the MaxEnt average ASCIIs were converted to rasters in ArcGIS. Then the threshold value was assigned to each model by reclassifying raster values to 0 for unsuitable habitat (< threshold) and 1 for potentially suitable habitat $(\geq$ threshold).

Then, the threshold-validated distribution models of each species were combined in one model using raster calculator in ArcGIS. After that, raster appeared in the display looking with a different colour scheme allow us to determine the areas of high species richness across Saudi Arabia's Red Sea coast.

\section{Results}

\section{Individual species models}

The performance was generally high for all individual species models. The mean AUC ranged from 0.532 and 0.990 . The key significant variables for the 22 wetlandbird species distribution models are summarised in Table 2.

\section{All birds}

The species distribution model generated when using all bird species occurrence data showed that the most suitable habitats for wetland birds were predicted to be in the middle and southern parts of the Red Sea coast (Fig. 2). The results of the jackknife test (Fig. 3) revealed that the coast complexity is the key variable in explaining the distribution of all birds. This variable introduced a higher gain compared to the other variables and would likely be highly influential if withdrawn from the model. Models using slope alone do not perform well and thus would be the least transferable. The next two variables that contributed the most to the model are distance to main cities and distance to roads. 
Table 2. Summary statistics of the 22 wetland bird species on the Red Sea coat of Saudi Arabia including species occurrence data, variable with highest gain (from jackknife test of variable importance), percent contribution of top two contributors to each model (from the table of relative contributions of the environmental variables), and the mean test AUC for each model

\begin{tabular}{|c|c|c|c|c|c|c|c|}
\hline Species & $\begin{array}{c}\text { Occurrence } \\
\text { records }\end{array}$ & $\begin{array}{c}\text { Variable with highest } \\
\text { gain }\end{array}$ & $\begin{array}{c}\text { The first important } \\
\text { variable }\end{array}$ & $\begin{array}{c}\text { Percent } \\
\text { contribution }\end{array}$ & $\begin{array}{c}\text { The second important } \\
\text { variable }\end{array}$ & $\begin{array}{c}\text { Percent } \\
\text { contribution }\end{array}$ & $\begin{array}{c}\text { Mean } \\
\text { test AUC }\end{array}$ \\
\hline Eurasian Spoonbill & 17 & Distance to cities & Distance to cities & 53.6 & Latitude & 23.1 & 0.895 \\
\hline Intermediate Egret & 30 & Distance to main cities & Distance to main cities & 32 & Elevation & 23.4 & 0.774 \\
\hline Westem Reef Heron & 47 & Coast complexity & Latitude & 31.7 & Distance to road & 25.7 & 0.853 \\
\hline Pink-backed Pelican & 14 & Distance to cities & Coast complexity & 36.6 & Distance to cities & 36.1 & 0.900 \\
\hline Eurasian Oystercatcher & 14 & Distance to cities & soil moisture & 38.5 & Distance to cities & 35.8 & 0.619 \\
\hline Crab Plover & 190 & Coast complexity & Coast complexity & 28.4 & Distance to main cities & 23.7 & 0.914 \\
\hline Kentish Plover & 766 & Distance to main cities & Distance to main cities & 27.3 & Coast complexity & 26.5 & 0.896 \\
\hline Lesser Sand Plover & 210 & Coast complexity & Coast complexity & 31.8 & Distance to main cities & 30.2 & 0.906 \\
\hline Greater sand plover & 139 & Coast complexity & Coast complexity & 29.9 & Distance to road & 23.5 & 0.914 \\
\hline Whimbrel & 50 & Distance to road & Distance to road & 54.2 & Distance to cities & 18.5 & 0.820 \\
\hline Eurasian Curlew & 51 & Distance to road & soil moisture & 25.1 & Coast complexity & 19.8 & 0.881 \\
\hline Redshank & 119 & Coast complexity & Coast complexity & 30.2 & Distance to road & 23 & 0.890 \\
\hline Marsh Sandpiper & 33 & Distance to road & Distance to road & 30 & Latitude & 29.6 & 0.836 \\
\hline Terek Sandpiper & 21 & Distance to road & Distance to road & 70.1 & soil moisture & 9.5 & 0.729 \\
\hline Ruddy Tumstone & 59 & Coast complexity & Coast complexity & 30.9 & Distance to cities & 24.4 & 0.791 \\
\hline White-eyed Gull & 20 & Latitude & latitude & 33.1 & Distance to cities & 21.6 & 0.990 \\
\hline Sooty Gull & 73 & Coast complexity & Distance to main cities & 24.8 & Distance to cities & 18.9 & 0.819 \\
\hline Caspian Tem & 26 & Distance to road & Distance to road & 49.3 & Coast complexity & 13.1 & 0.853 \\
\hline Swift Tem & 15 & Distance to cities & Distance to cities & 37.2 & Distance to road & 34 & 0.723 \\
\hline Lesser Crested Tem & 25 & Slope & Slope & 29.3 & Latitude & 25.2 & 0.532 \\
\hline Saunders's Tem & 19 & Distance to road & Distance to road & 24.5 & Distance to cities & 22.3 & 0.878 \\
\hline White-cheeked Tem & 16 & vegetation cover & vegetation cover & 33.1 & soil moisture & 21.6 & 0.612 \\
\hline
\end{tabular}

An examination of the model response curves to key environmental variables indicated that the greater the value of the distance to main cities and soil moisture, the greater the value of the potential habitat suitability, while the greater the value of the coast complexity, distance to roads, distance to cities and elevation variables, the smaller the value of the potential habitat suitability.

The "All birds" model suggested that approximately $17 \%$ of the Red Sea coastal habitat is suitable for wetland bird species.

\section{Model validation}

The "All birds" model performed well in predicting the presence of all birds when evaluated using a ROC plot (AUC mean $=0.901$ and 0.879 for the training and testing data, respectively). This result indicated that in the final model, a cell predicted as suitable habitat at any threshold of suitability would be more suitable than a randomly selected cell in the study area at least $87 \%$ of the time. 


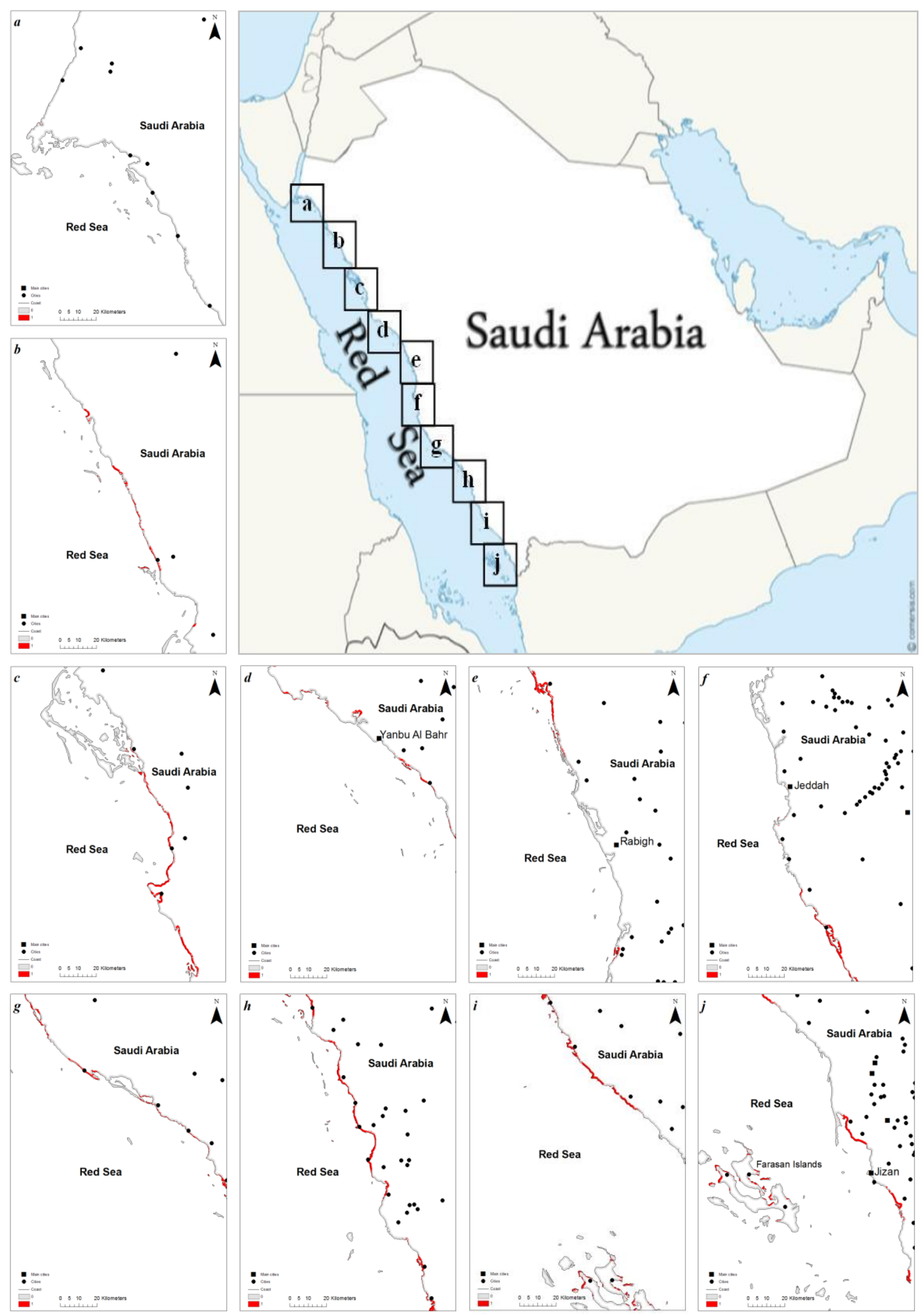

Figure 2. Maps showing the predicted potential suitable habitats for "All birds" (50\% training data and 50\% test data); using Maximum training sensitivity plus specificity threshold; red line represent potential habitat suitability for "All birds". The square black dots represent the main cities and circle black dots represent the cities 


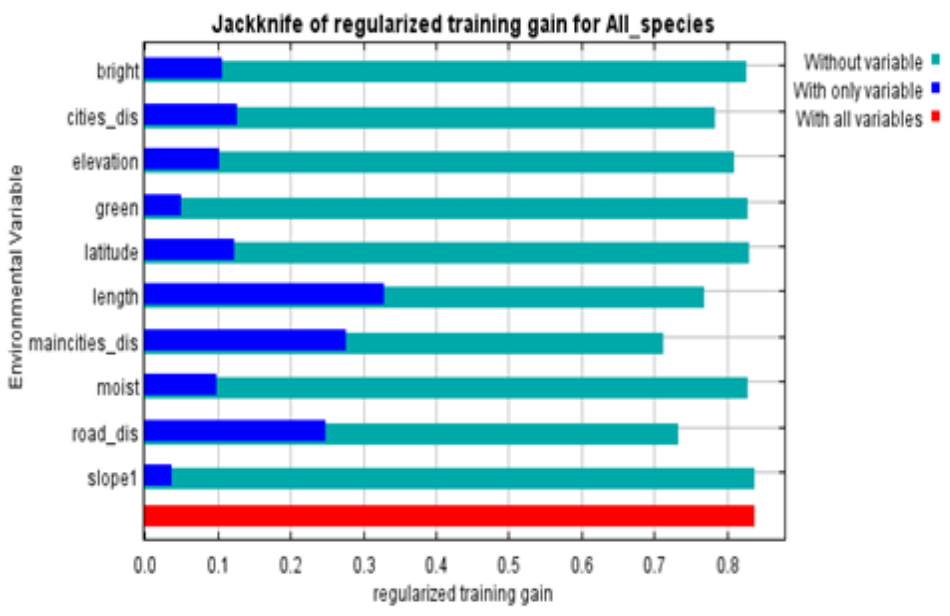

\begin{tabular}{|c|c|c|}
\hline Variable & $\begin{array}{c}\text { Percent } \\
\text { contribution }\end{array}$ & $\begin{array}{c}\text { Permutation } \\
\text { importance }\end{array}$ \\
\hline maincities dis & 23 & 17.3 \\
\hline length & 22.3 & 31.3 \\
\hline road_dis & 19.9 & 21 \\
\hline cities dis & 11.8 & 6.9 \\
\hline elevation & 7.6 & 9.5 \\
\hline moist & 5.6 & 1.4 \\
\hline bright & 4.8 & 0.9 \\
\hline latitude & 3 & 8.8 \\
\hline green & 1.7 & 2.7 \\
\hline slopel & 0.2 & 0.2 \\
\hline
\end{tabular}

Figure 3. Results of jackknife evaluations of relative importance of predictor variables and table gives estimates of relative contributions of the environmental variables for "All birds" using Maxent model. Note: 'bright is brightness; 'cities_dis' is distance to cities; 'green' is vegetation cover, 'length' is coast complexity, 'maincities_dis' is distance to main cities, 'moist' is soil moisture, 'road_dis' is distance to road

\section{Species richness areas}

The areas of high species richness for wetland birds in the Red Sea coastal area are illustrated in the map shown in Figure 4, which reveals that 17 areas may represent potentially suitable habitats for a large number of wetland bird species. Furthermore, the map illustrates that areas of the Red Sea coast were predicted as suitable habitat for up to 19 species, particularly in the middle and southern parts of the Red Sea coast. In contrast, the northern part of the Red Sea coast contains only two areas of high species richness. The areas of high species richness appear fragmented in places and cover broad distances along the study area. The majority of endemic and near-threatened species occurs in all 17 areas, except the White-eyed Gull, which occurs only in two areas located in the northern part of the Red Sea coast (Table 3). 


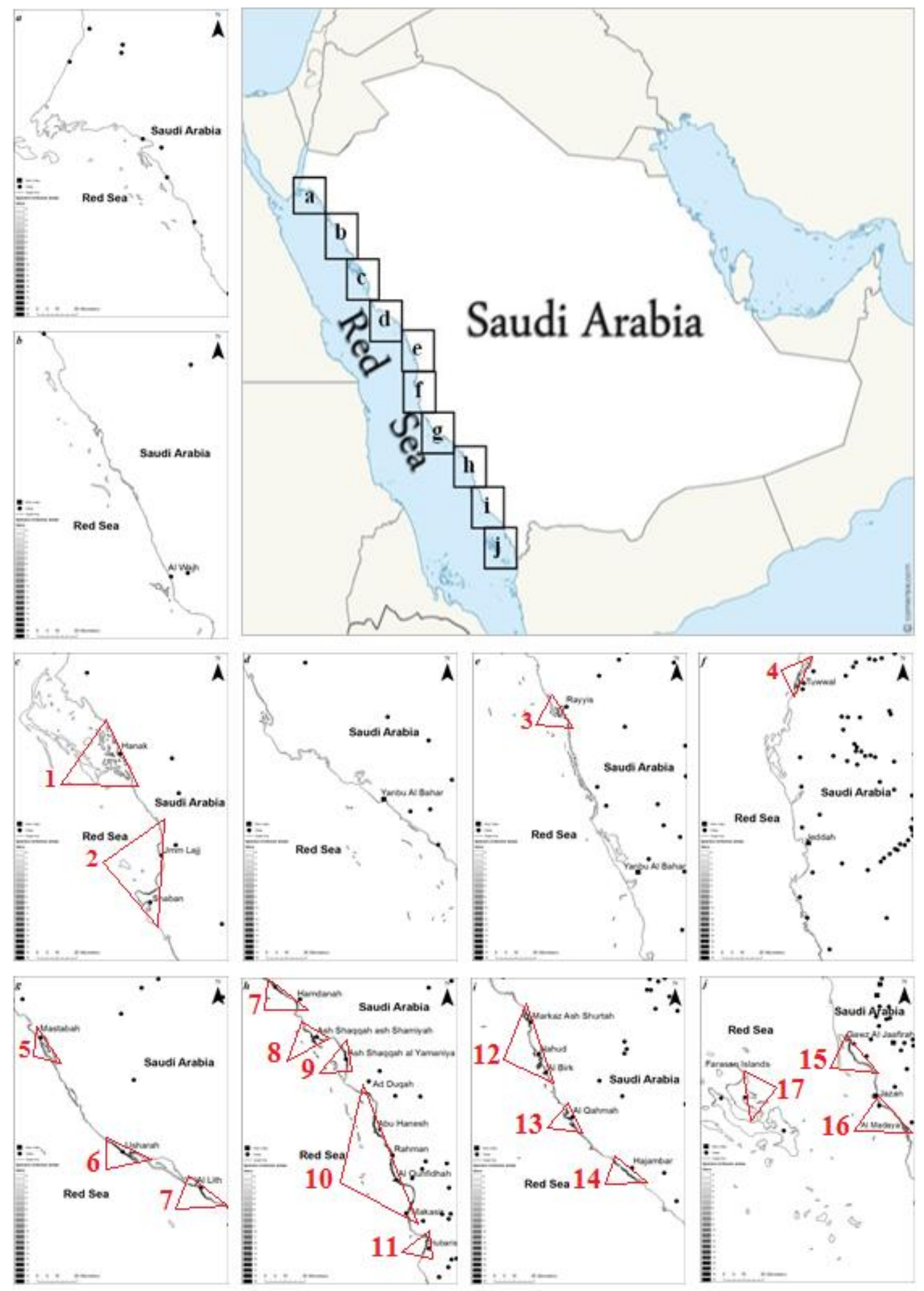

Figure 4. Maps showing the 17 final predicted areas of high species richness for wetland birds in the Red Sea coast of Saudi Arabia. The red triangles indicate the potential areas of high species richness. The square black dots represent the main cities and circle black dots represent the cities 
Table 3. Showing all 17 locations that are considered potentially suitable habitats for wetland birds along the Red Sea coast of Saudi Arabia, the locations of the endemic and near-threatened species that occurs in all 17 sites and the total species numbers that occur in each potential suitable habitat

\begin{tabular}{|c|c|c|c|c|c|c|c|c|}
\hline \multirow{3}{*}{ No. } & \multirow{3}{*}{ Sites } & \multicolumn{6}{|c|}{ Species } & \multirow{3}{*}{$\begin{array}{c}\text { Number } \\
\text { of species } \\
\text { occur in } \\
\text { potential } \\
\text { suitable } \\
\text { habitats }\end{array}$} \\
\hline & & \multirow{2}{*}{\begin{tabular}{|c|} 
Crab \\
Plover \\
$\begin{array}{c}\text { Endemic } \\
\text { LC }\end{array}$ \\
\end{tabular}} & \multirow{2}{*}{$\begin{array}{c}\begin{array}{c}\text { Eurasian } \\
\text { Curlew }\end{array} \\
\text { NT }\end{array}$} & \multirow{2}{*}{$\begin{array}{c}\begin{array}{c}\text { White- } \\
\text { eyed } \\
\text { Gull }\end{array} \\
\begin{array}{c}\text { Endemic } \\
\text { NT }\end{array}\end{array}$} & \multirow{2}{*}{$\begin{array}{c}\begin{array}{c}\text { Sooty } \\
\text { Gull }\end{array} \\
\begin{array}{c}\text { Endemic } \\
\text { LC }\end{array}\end{array}$} & \multirow{2}{*}{$\begin{array}{c}\begin{array}{c}\text { Saunders's } \\
\text { Tern }\end{array} \\
\text { Endemic } \\
\text { LC }\end{array}$} & \multirow{2}{*}{$\begin{array}{c}\begin{array}{c}\text { White- } \\
\text { cheeked } \\
\text { Tern }\end{array} \\
\text { Endemic } \\
\text { LC }\end{array}$} & \\
\hline & & & & & & & & \\
\hline 1 & $\begin{array}{l}\text { Hanak and } \\
\text { the islands } \\
\text { around it } \\
\text { From }\end{array}$ & $\sqrt{ }$ & $\sqrt{ }$ & $\sqrt{ }$ & $\sqrt{ }$ & $\mathrm{X}$ & $\sqrt{ }$ & 18 \\
\hline 2 & $\begin{array}{l}\text { Umm Lujj to } \\
\text { Shaban }\end{array}$ & $\sqrt{ }$ & $\sqrt{ }$ & $\sqrt{ }$ & $\sqrt{ }$ & $\mathrm{X}$ & $\sqrt{ }$ & 16 \\
\hline 3 & Rayyis & $\sqrt{ }$ & $\sqrt{ }$ & $\sqrt{ }$ & $\sqrt{ }$ & $\sqrt{ }$ & $\sqrt{ }$ & 16 \\
\hline 4 & Thuwwal & X & $\sqrt{ }$ & X & $\sqrt{ }$ & $\sqrt{ }$ & $\sqrt{ }$ & 18 \\
\hline 5 & Mastabah & & $\sqrt{ }$ & X & $\sqrt{ }$ & $\sqrt{ }$ & $\sqrt{ }$ & 17 \\
\hline 6 & Usharah & $X$ & $\sqrt{ }$ & $\mathrm{X}$ & $\sqrt{ }$ & $\sqrt{ }$ & $\sqrt{ }$ & 18 \\
\hline 7 & $\begin{array}{l}\text { From Alith } \\
\text { to } \\
\text { Hamdanah }\end{array}$ & $\sqrt{ }$ & $\sqrt{ }$ & $\mathrm{X}$ & $\sqrt{ }$ & $\sqrt{ }$ & $\mathrm{X}$ & 19 \\
\hline 8 & $\begin{array}{l}\text { Ash Shaqqah } \\
\text { Ash } \\
\text { Shammiyah }\end{array}$ & $\sqrt{ }$ & $\sqrt{ }$ & $\mathrm{X}$ & $\sqrt{ }$ & $\sqrt{ }$ & $\mathrm{X}$ & 19 \\
\hline 9 & $\begin{array}{c}\text { Ash Shaqqah } \\
\text { Al } \\
\text { Yamaniya } \\
\text { East Ad }\end{array}$ & $\sqrt{ }$ & $\sqrt{ }$ & $\mathrm{X}$ & $\sqrt{ }$ & $\sqrt{ }$ & $\mathrm{X}$ & 19 \\
\hline 10 & $\begin{array}{l}\text { Duqah } 7 \mathrm{~km} \\
\text { to Makasir }\end{array}$ & $\sqrt{ }$ & $\sqrt{ }$ & $\mathrm{X}$ & $\sqrt{ }$ & $\sqrt{ }$ & $\mathrm{X}$ & 19 \\
\hline 11 & $\begin{array}{l}\text { Hubaris } \\
\text { From }\end{array}$ & $\sqrt{ }$ & $\sqrt{ }$ & $\mathrm{X}$ & $\sqrt{ }$ & $\sqrt{ }$ & $\mathrm{X}$ & 18 \\
\hline 12 & $\begin{array}{l}\text { Markaz Ash } \\
\text { Shurtah to } \\
\text { Al Birk }\end{array}$ & $\sqrt{ }$ & $\sqrt{ }$ & $\mathrm{X}$ & $\sqrt{ }$ & $\sqrt{ }$ & $\sqrt{ }$ & 17 \\
\hline 13 & $\begin{array}{l}\text { Al Qahmah } \\
\text { West }\end{array}$ & $\sqrt{ }$ & $\sqrt{ }$ & $\mathrm{X}$ & $\sqrt{ }$ & $\sqrt{ }$ & $\mathrm{X}$ & 17 \\
\hline 14 & $\begin{array}{c}\text { Hajambar } 3 \\
\text { km }\end{array}$ & $\sqrt{ }$ & $\sqrt{ }$ & $\mathrm{X}$ & $\sqrt{ }$ & $\sqrt{ }$ & $\mathrm{X}$ & 17 \\
\hline 15 & $\begin{array}{l}\text { Qawz Al } \\
\text { Jaafirah }\end{array}$ & $\sqrt{ }$ & $\sqrt{ }$ & $\mathrm{X}$ & $\sqrt{ }$ & $\sqrt{ }$ & $\mathrm{X}$ & 16 \\
\hline 16 & $\begin{array}{c}\text { From Jazan } \\
\text { to At } \\
\text { Tahiriyah } \\
\text { The East } \\
\text { shoreline of }\end{array}$ & $\sqrt{ }$ & $\sqrt{ }$ & $\mathrm{X}$ & $\sqrt{ }$ & $\sqrt{ }$ & $\mathrm{X}$ & 15 \\
\hline 17 & $\begin{array}{l}\text { Al Segied } \\
\text { Island in } \\
\text { Farasan } \\
\text { Islands } \\
\end{array}$ & $\sqrt{ }$ & $X$ & $\mathrm{X}$ & $\mathrm{X}$ & $\mathrm{X}$ & $\sqrt{ }$ & 11 \\
\hline
\end{tabular}




\section{Discussion}

This study provides the first predicted potential habitat suitability maps for 22 wetland bird species along the Red Sea coast in the KSA. Although we built some models with occurrences data less than 20 locations, MaxEnt proved to give a robust performance in practice compared to other methods and remains effective despite a small sample size (Elith et al., 2006; Baldwin, 2009). The results demonstrated distance to cities, distance to roads and coast complexity variables influence negatively quite a few wetland bird species. These effect may be mediated through human activities (e.g disturbance, hunting and pollution), and the risk of predation by introduced cats, dogs and crows in the vicinity of settlements (AlRashidi et al., 2011). Furthermore, Findlay and Houlahan (1997) found that there is highly negative correlation between bird species richness and road within around $1 \mathrm{~km}$ of a wetland. Many studies have been indicated that some bird species avoid selecting habitats near the roads (Bollinger and Gavin 2004, Carrascal et al., 2006, Gavashelishil and McGrady, 2006). Roads have highly influence on birds in different directions such as, direct mortality, indirect mortality, habitat fragmentation, isolation and disturbance (Jacobson, 2005; Findlay and Bourdages, 2000).

Several wetland bird species that have particular importance in terms of conservation status are present on the Red Sea coast. These species include Crab Plovers (Dromas ardeola), White-eyed Gulls, Sooty Gulls, and White-cheeked Terns (PERSGA/GEF, 2003). Due to their importance in regional conservation strategies, these specific species will be discussed below in light of the potential species distribution models.

Crab Plover. Crab Plovers are known to utilise areas of sandy and muddy coastline on islands, intertidal sandflats and mudflats, estuaries, lagoons, and bare coral reefs (Burton and Burton, 2002), and breed on sandy islands or extensive coastal sandy banks (BirdLife International, 2013). Examining the habitat suitability model the distance to main cities and soil moisture have a positive influence on the distribution of Crab Plovers, whereas, coast complexity, distance to cities and distance to roads have a negative influence on their distribution.

White-eyed Gull. White-eyed Gulls are known to utilise coastal areas and breed on island shorelines on exposed rock and sand flats (del Hoyo et al., 1996). Although some populations in Egypt have been shown to get their food from drifting litter and harbours (Baha El Din, 1999), the species mostly feeds at sea (PERSGA/GEF, 2003). Examining the habitat suitability model the latitude has a positive influence on the distribution of White-eyed Gulls, whereas the distance to cities, vegetation cover and slope have a negative influence on their distribution.

Sooty Gulls. Sooty Gulls which are known to utilise areas of along coast and at islands and breed on coastal and inshore islands near sea level which are sparsely vegetated, rocky and sandy (Cramp and Simmons, 1983, PERSGA/GEF, 2004). Furthermore, sometimes they feed in mudflat and rest in harbours and unusually seen inland (del Hoyo et al., 1996). Examining the habitat suitability model the distance to main cities, distance to roads and latitude have a positive influence on the distribution of Sooty Gulls, whereas the coast complexity and distance to cities have a negative influence on their distribution.

White-cheeked Tern. White-cheeked Terns are known to utilise coastal areas and along inshore bodies of water. They nest on rock, sand, gravel, and coral islands (del Hoyo et al., 1996), as well as on the exposed sandflats and sparsely vegetated open 
ground of sand dunes and above shorelines' high-water marks (Snow and Perrins, 1998). Examining the habitat suitability model the soil moisture and latitude have a positive influence on the distribution of White-cheeked Terns, whereas the vegetation cover and distance to main cities have a negative influence on their distribution. Saudi Arabia is generally an arid country with very high temperatures in summer. It receives about $70 \mathrm{~mm}$ of precipitation annually. Therefore, these factors led to decreased vegetation cover (Darfaoui and Al Assiri, 2011).

Kentish Plover. It is encouraging to compare our model results for the Kentish Plover with those reported by AlRashidi et al., (2011). He used a Generalised Linear Model (GLM) with four habitat variables elevation, distance to settlements, vegetation cover and soil moisture for predicting potential suitable habitat for Kentish Plover. In particular, AlRashidi et al., (2011) reported that the most suitable habitat for Kentish Plovers on the Farasan Islands is located on the northern and eastern shores; this result is consistent with the findings of the present study. Furthermore, AlRashidi et al., (2011) found the most suitable continental habitat for the Kentish Plover species to be located in two concentrated areas along the Red Sea coast. The first area is located between Yanbu Al Bahr and Jiddah, and lies approximately $100 \mathrm{~km}$ south of Jiddah. The second area is located near the city of Jazan. However, our study predicted the most suitable continental habitat patches for the Kentish Plover to be located along the Red Sea coast south of the cities Hanak and Jazan.

\section{Mapping areas of high species richness}

This study provided the first predicted potential habitat richness map for wetland bird species along the Red Sea coast of Saudi Arabia. Mapping species richness and distributions has become a key strategy in conservation planning (Cardillo, 1999; Graham and Hijmans, 2006). Identifying species richness areas that include endemic species will provide conservation agencies and practitioners with the information needed to develop and optimise conservation strategies and actions (Bojórquez-Tapia et al., 1995).

Each of the 17 areas of high wetland bird species richness that were identified in this study contains different levels of endemic species. We already know that wetland birds and their habitats along the Red Sea coast face many threats. Therefore, a survey of these 17 areas should be undertaken in the future in order to investigate the actual presence of wetland birds in these areas and to thereby determine the most significant of these 17 areas for conservation purposes.

\section{Potential Sources of error}

Several studies have indicated that environmental variables, such as habitat structure and composition, play important roles in improving the accuracy of bird habitat descriptions (Dettmers and Bart, 1999). The advantage of species modelling techniques is that they can be used to estimate the potential conservation value of both surveyed and under-surveyed areas (Maddock and Du Plessis, 1999). However, Osborne et al., (2001) pointed out two potential issues when building predictive models for species distribution over large regions. First, there may be problems related to the consistency of predictor variables over large geographic spaces, which is particularly apparent in variables derived from remote sensing because of the inherent variability of angular 
surface reflectance (Stoms, 1992). The second issue concerns the variations in habitat selection among individual birds.

\section{Implications for conservation}

The conservation of wetland bird habitats has become a global conservation priority (BirdLife International, 2011). The species distribution model presented in this study can be used to underpin future conservation planning in the Red Sea region (Guisan and Thuiller, 2005). The "All birds" model in this study indicated that approximately 17\% of the Red Sea coastal habitat is suitable for wetland bird species.

In Saudi Arabia, there are 15 protected areas; only two of these (the Farasan Islands and the Umm Al Qamarie Islands) are located along the shores of the Red Sea (Saudi Wildlife Commission, 2011). Thus, we recommend that future monitoring and surveys should be carried out to cover all 17 areas of high wetland bird species richness along the Red Sea coast in order to determine the most significant coastal areas for wetland bird species and therefore, incorporate them into the protected areas system in the future. These areas should include both nesting and foraging sites for wetland bird species. Furthermore, we strongly recommend that establishing new protected areas along the Red Sea coast line are becoming priority to protect in particular the remain suitable habitat areas for threatened and endemic wetland birds.

\section{Conclusions}

This study has produced the first predicted potential habitat distribution maps for wetland bird species along the Red Sea coast of the Kingdom of Saudi Arabia. It has revealed that there are 17 important areas of species richness for wetland birds along the Red Sea coast of the KSA. Understanding the correlation between species occurrence and environmental variables will help both researchers and policy makers to implement appropriate conservation plans in terms of wetland bird species. The modelling presented here has the potential to form the basis for conservation strategy of wetland birds in the Red Sea coastal region of Saudi Arabia, and it is hoped that this study will guide future field surveys and conservation programs in the Red Sea coast areas of Saudi Arabia.

Acknowledgments. Financial support was provided by the Ministry of Higher Education in Saudi Arabia, University of Taif. We thank the Saudi Wildlife Commission (SWC), represented by SWC Secretary-General Prince Bandar bin Saud, for help in logistics and for providing facilities in the field. We also wish to extend our thanks to Kate Ashbrook for her comments and professional remarks.

\section{REFERENCES}

[1] AbuZinada, A.H., Robinson E.R., Nader, A.I., Al Wetaid, Y.I. (Eds.) (2002): First Saudi Arabian National Report on the Convention on Biological Diversity. The National Commission for Wildlife Conservation and Development: Ryad, $131 \mathrm{pp}$.

[2] AlRashidi, M., Long, P.R., O’Connell, M., Shobrak, M., Székely, T. (2011): Use of remotesensing to identify suitable breeding habitat for the Kentish Plover and estimate population size along the western coast of Saudi Arabia. - Wader Study Group Bull 118(1): 32-39. 
[3] Austin, G.E., Thomas, C.G., Houston, P.C., Thompson, P.B.A. (1996): Predicting the spatial distribution of buzzard Buteo buteo nesting areas using a geographic information system and remote sensing. - Applied Ecology 33: 1541-1550.

[4] Baha El Din, S. M. (1999): Directory of Important Bird Areas in Egypt. - BirdLife International, Cairo.

[5] Baldwin, R.A. (2009): Use of Maximum Entropy Modeling in Wildlife Research. Entropy 11: 854-866.

[6] BirdLife International (2011): Birds on the IUCN Red List. In: Presented as Part of the BirdLife State of the World's Birds Website.

<http://www.birdlife.org/action/science/species/global_species_programme/red_list.html. Accessed 20/11/2011>.

[7] BirdLife International (2013): Crab Plover Dromas ardeola. In: Presented as Part of the BirdLife State of the World's Birds Website. <http://www.birdlife.org/datazone/speciesfactsheet.php?id=3177. Accessed 18/06/2013>.

[8] BirdLife International (2012): Wetland conservation in Madagascar. In: Presented as Part of the BirdLife State of the World's Birds Website.

<http://www.birdlife.org/action/ground/madagascar/index.html. Accessed 23/01/2012>.

[9] Bojórquez-Tapia, L.A., Azuara, I., Ezcurra, E., Flores-Villela, O. (1995): Identifying conservation priorities in Mexico through geographic information systems and Modelling. - Ecological Applications 5: 215-231.

[10] Bollinger, E. K., Gavin, T. A. (2004): Responses of nesting bobolinks Dolichonyx oryzivorus to habitat edges. - Auk 121: 767-776.

[11] Buckland, S.T., Elston, D.A., Beaney, S.J. (1996) Predicting distributional change with application to bird distributions in Northeast Scotland. - Global Ecology and Biogeography Letters 5: 66-84.

[12] Burton, M., Burton, R. (2002): International Wildlife Encyclopedia. - Marshall Cavendish, New York.

[13] Cardillo, M., Macdonald D.W., Rushton S.P. (1999): Predicting mammal species richness and distributions: testing the effectiveness of satellite-derived land cover data.Landscape Ecology 14: 423-435.

[14] Carrascal, L.M, Seoane, J. Palomino, D., Alonso, C. L. (2006): Habitat preferences,population size and demographic trends of Houbara Bustard Chlamydotis undulata inLanzarote and La Graciosa (Canary Islands). - Ardeola 53: 251-269.

[15] Cramp, S., Simmons, K.E.L. (1983): Handbook of the birds of Europe, the Middle East and Africa. The birds of the western Palearctic vol. III: waders to gulls. - Oxford University Press, Oxford.

[16] Crist, E.P., Cicone, R.C. (1984): Application of the tasseled cap concept to simulated thematic mapper data. Photogram. - Eng. Rem. Sens 50: 343-352.

[17] Darfaoui, E. M., Al Assiri, A. (2011): Response to climate change in the Kingdom of Saudi Arabia. Internal working paper, Cairo, Egypt, FAO RNE.

[18] del Hoyo, J., Elliott, A., Sargatal, J. (1996): Handbook of the birds of the world. Vol 3: Hoatzin to Auks. - Lynx Edicions, Barcelona.

[19] Dettmers, R., Bart, J. (1999): A GIS modeling method applied to predicting forest songbird habitat. - Ecological Applications 9: 152-163.

[20] Elith, J., Leathwick, J. (2009): Species distribution models: Ecological explanation and prediction across space and time. - Annual Review of Ecology, Evolution and Systematics 40: 677-697.

[21] Elith, J., Graham, C. H., Anderson, R. P., Dudik, M., Ferrier, S., Guisan, A., Hijmans, R. J., Huettman, F., Leathwick, J. R., Lehmann, A., Li, J., Lohmann, L. G., Loiselle, B. A., Mannion, G., Moritz, G., Nakamura, M., Nakazawa, Y., Overton, J. M. M., Peterson, A. T., Phillips, S. J., Richardson, K., Scachetti- Pereira, R., Schapire, R. E., Sobero'n, J., Williams, S.,Wisz, M. S., Zimmermann,N. E. (2006): Novel methods improve prediction of species' distributions from occurrence data. - Ecography 29: 129-151. 
[22] Findlay, C.S, Houlahan, J. (1997): Anthropogenic correlates of species richness in southeastern Ontario wetlands. - Conservation Biology 11: 1000-1009.

[23] Findlay, C.F., Bourdages, J. (2000): Response time of wetland biodiversity to road construction on adjacent lands. - Conservation Biology 14: 86-94.

[24] Franklin, J. (2009): Mapping Species Distributions: Spatial Inference and Prediction.Cambridge University Press, Cambridge.

[25] Gavashelishili, A., McGrady, M. J. (2006): Breeding site selection by Bearded Vulture Gypaetus barbatus and Eurasian Griffon Gyps fulvus in the Caucasus.- Animal Conservation 9: 159-170.

[26] Graham, C.H., Elith, J., Hijmans, R., Guisan, A., Peterson, A.T., Loiselle, B.A., NCEAS Modeling Group. (2008): The influence of spatial errors in species occurrence data used in distribution models. - Journal of Applied Ecology 45: 239-247.

[27] Graham, C.H., Hijmans, R.J. (2006): A comparison of methods for mapping species ranges and species richness. - Global Ecology and Biogeography 15: 578-587.

[28] Guisan, A., Thuiller, W. (2005): Predicting species distribution: offering more than simple habitat models. - Ecology Letters 8: 993-1009.

[29] IUCN (2012): IUCN Red List of Threatened Species (Version 2012.2). <www.iucnredlist.org. Accessed 26 June 2012>.

[30] Guisan, A., Zimmermann, N. E. (2000): Predictive habitat distribution models in ecology. - Ecological Modelling 135 (2-3): 147-186.

[31] Huang, C., Wylie, B., Yang, L., Homer, C., Zylstra, G. (1998): Derivation of a tasseled cap transformation based on Landsat 7 at-satellite reflectance. Sioux Falls, SD, USA: Raytheon ITSS, USGS EROS Data Center. [Available at http://landcover.usgs.gov/pdf/tasseled.pdf ].

[32] Jacobson, S. L. (2005): Mitigation measures for highway-caused impacts to birds. In C. J. Ralph and T. D. Rich (eds.). USDA Forest Service General Technical Report PSWGTR191,Volume I and II, 1043-1050. Forest Service, U.S. Department of Agriculture. 1294 pp.

[33] Jiménez-Valverde A., Lobo J.M. (2007): Threshold criteria for conversion of probability of species presence to either-or presence-absence. - Acta Oecol 31: 361-369.

[34] Kauth, R.J., Thomas, G.S. (1976): The tasseled cap - a graphic description of the spectral temporal development of agricultural crops as seen by Landsat. Proceedings of the symposium on machine processing of remotely sensed data, Perdue University, West Lafayette, IN, pp. 41-51.

[35] Ledee, O.E.; Cuthbert, F.J., Bolstad, P.V. (2008): A remote sensing analysis of coastal habitat composition for a threatened shorebird, the piping plover (Charadrius melodus). Journal of Coastal Research 24: 719-726.

[36] Long, P. R., Zefania, S., ffrench-ConstantR. H., Szekely,T. (2008): Estimating the population size of an endangered shorebird, the Madagascar plover, using a habitat suitability model. - Animal Conservation 11: 118-127.

[37] Maddock, A., Du Plessis M.A. (1999): Can species data only be appropriately used to conserve biodiversity? Biodiversity and Conservation 8: 603-615.

[38] Milsom, T.P., Langton, S.D., Parkin, W.K., Peel, S., Bishop, J.D., Hart J.D., \& Moore, N.P. (2000): Habitat models of species distribution: an aid to the management of coastal grazing marshes. -Applied Ecology 37: 706-727.

[39] Newton, S.F. (2006): Regional Organization for the Conservation of the Environment of the Red Sea and Gulf of Aden (PERSGA) Implementation of the Strategic Action Programme (SAP) for the Red Sea and Gulf of Aden Guide to Standard Survey Methods for Seabirds. Saudi Arabia, PERSGA.

[40] Osborne, P., Alonso, J.C., Bryant, R.G. (2001): Modelling landscape-scale habitat use using GIS and remote sensing: a case study with great bustards. - Applied Ecology 38: 458-471. 
[41] Pearce, J., Ferrier, S. (2000): An evaluation of alternative algorithms for fitting species distribution models using logistic regression. - Ecological Modelling 128: 127-147.

[42] PERSGA/GEF (2003): Coral Reefs in the Red Sea and Gulf of Aden. Surveys 1990 to 2000 Summary and Recommendations. PERSGA Technical Series No. 7.

[43] PERSGA/GEF (2004): Regional Action Plan for the Conservation of Breeding Seabirds and their Habitats in the Red Sea and Gulf of Aden. Jeddah, PERSGA.

[44] PERSGA/GEF (2003): Status of Breeding Seabirds in the Red Sea and Gulf of Aden. PERSGA Technical Series No. 8.

[45] Phillips, S.J., Anderson, R.P., Schapire, R.E. (2006): Maximum entropy modelling of species geographic distributions. - Ecological Modelling 190: 231-259.

[46] Phillips, S.J., Dudik, M. (2008): Modeling of species distributions with Maxent: new extensions and a comprehensive evaluation. - Ecography 31: 161-175.

[47] Rodriguez, J.P., Brotons, L., Bustamante, J., Seoane, J. (2007): The application of predictive modelling of species distribution to biodiversity conservation. - Diversity and Distributions 13: 243-251.

[48] Rushton, S. P., Ormerod, S. J., Kerby, G. (2004): New paradigms for modelling species distributions? - Applied Ecology 41: 193-200.

[49] Saudi Wildlife Commission (2011): Protected Areas. <http://www.swc.gov.sa/English/protectedareas.aspx. Accessed 23/01/2012>.

[50] Suárez-Seoane, S., García de la Morena, E.L., Morales, M. B., Osborne, P.E., De Juana, E. (2008): Maximum entropy niche-based modelling of seasonal changes in little bustard (Tetrax tetrax) Distribution. - Ecological Modelling 219: 17-29.

[51] Stoms, D. M. (1992): Effects of habitat map generalization in biodiversity assessment. Photogrammetric Engineering and Remote Sensing 58: 1587-1591.

[52] Thomas, C.D., Cameron, A., Green, R.E., Bakkenes, M., Beaumont, L.J., Collingham, Y.C., Erasmus, B.F.N., Ferriera de Siquiera, M., Grainger, A., Hannah, L., Hughes, L., Huntley, B., van Jaarsveld, A.S., Midgley, G.F., Miles, L., Ortega-Huerta, M.A., Townsend-Peterson, A., Phillips, O.L., Williams, S.E. (2004): Extinction risk from climate change. - Nature 427: 145- 148.

[53] Young, B. E., Franke, I., Hernandez, P. A., Herzog, S. K., Paniagua, L., Tovar, C., Valqui, T. (2009): Using Spatial Models to Predict Areas of Endemism and Gaps in the Protection of Andean Slope Birds. - The Auk 126: 554-565. 